\title{
Human Asset Accounting And Measurement: Moving Forward
}

Brian B. Stanko, Loyola University of Chicago, USA

Thomas L. Zeller, Loyola University of Chicago, USA

Matthew F. Melena, Cleveland State University, USA

\begin{abstract}
Changes in the accounting profession and in the way organizations are managed and operated over the past several decades have led to the identification of a new factor that makes up a substantial part of the value of an organization: human capital. The value that employees add to organizations, however, has been difficult to measure because of the many elements that comprise it and aspects of human nature and free will that are involved. Many models have been proposed to capture the value that organizations gain from employees, but none have succeeded in full. Additionally, strict financial reporting regulations would require an accurate and uniform method of accounting for human capital in order to give much relevance to the data collected. Despite its complex nature, the field of human asset accounting continues to gain momentum and is headed in the right direction. The development of a universal method of accounting for human capital would provide a much more exact valuation of organizations and have deep benefits for owners, managers, investors, accountants, and human resource employees. This paper examines the history of human asset accounting and its feasibility in current financial reporting environments. Additionally, it demonstrates the importance of human asset accounting, different approaches toward human asset accounting, and how beneficial an accurate method could prove to be in financial reporting. Finally, the paper recommends that, as a precursor to measurement, the development of general quantitative and qualitative human capital disclosures, with real company examples, be included in a company's sustainability reporting.
\end{abstract}

Keywords: Human Asset Accounting; Human Capital; Human Resource

\section{INTRODUCTION}

"Management has come to accept that people, not cash, buildings, or equipment, are the critical differentiators of a business enterprise. ” Jac Fitz-enz, The ROI of Human Capital (2000)

$\mathrm{t}$ is considered conventional wisdom in the business world that most companies consider their employees to be their most important asset. Gary S. Becker, a Nobel Prize winner in the field of economics has claimed, "the basic resource in any company is the people. The most successful companies and the most successful countries will be those that manage human capital in the most effective and efficient manner" (Brocaglia, 2006, p. 2). This distinction, however, does not mean that human capital can be accounted for properly. Simply categorizing direct labor is not nearly an efficient enough means to measure human capital. Despite many attempts over the last several centuries, accountants and intellectuals have failed to establish an effective way to capture the true value that an employee brings a company.

Comprising such an important element of companies, it is clear that a method of accounting for human capital would vastly change the landscape of financial accounting and reporting. Not only would human resources departments be able to make significantly easier financial and personnel decisions, but management, lenders, and investors would have a much clearer understanding of a companies' financial health to use in decision-making.

Further, the global economy has been shifting from an industrial economy to an information-based economy as a result of the Internet and other new technologies. Therefore, human capital has become a greater 
benefit to companies than ever before. Other intangible assets can be accounted for with reasonable accuracy. Despite being much more complex than other intangible assets, it is still important that people in the accounting profession seek a method of accounting for human capital. Doing so would represent arguably the most monumental finding in the history of financial accounting, but until a reliable measure to report human capital is established, the Financial Accounting Standards Board cannot mandate that companies report that valuable information. Doing so would only produce inaccurate information leading to misguided decisions.

This paper examines the history of human asset accounting and its feasibility in current financial reporting environments. Additionally, it demonstrates the importance of human asset accounting, different methods of human asset accounting, and how beneficial an accurate method could prove to be in financial reporting.

\section{HUMAN CAPITAL ASSETS}

Human resource content expert Leslie A. Weatherly (2003) describes a company's human capital asset as "the collective sum of the attributes, life experience, knowledge, inventiveness, energy, and enthusiasm that its people choose to invest in their work" (p. 1). Many factors, including education, training, intelligence, internal and external relationships, and motivation, have been recognized as playing a role in human capital. Determining how much of a role each plays is what complicates the matter. Additionally, the fact that individuals have free will further complicates the issue. They can choose how much or how little effort they put into their work.

\section{HUMAN ASSET ACCOUNTING}

Human asset accounting aims to quantify, in dollar value, how valuable an employee is to the company that they are employed by. The American Accounting Association defines human asset accounting as "the human resources identification and measuring process and also its communication to the interested parties" (Parameswaran, 2005, p. 867). Human asset accounting includes assigning, budgeting, and reporting the cost of human resources in an organization.

There are several important aspects of human asset accounting as noted above. Accuracy in the measurement of an employee's worth is crucial to the process. Despite the difficulty in quantifying employee value, doing so precisely is critical to beneficial human asset accounting. This leads into reporting, the other imperative aspect of human asset accounting. Strong reporting is essential. Without properly conveying the value measured correctly, stakeholders and decision-makers cannot obtain worth from the entire process.

\section{A Company's Most Important Asset}

The majority of companies consider their employees to be their most important asset. It is a cliché used in many companies' mission and vision statements, but also a reality for most companies. This is especially true in service industries. Ironically, this asset is not taken into consideration in the accounting of companies due to its elusive nature. Because they are unable to effectively account for employees as assets, a very important aspect of a company's financials are not taken into consideration, which can often lead to misrepresentation of a company's financial health. Instead, only expenses associated with the employee, such as salary and training, are represented in the financial statements of a company. This counteracts the idea that employees are an investment. Therefore, a company's financials suggest that expenses related to employees are sunken costs that have no future benefit. Any wise executive will argue that this could not be further from the reality of the situation. An organization could have all of the world's information and machinery, but it would be useless without the right people there to convert that into production.

In an article in the Journal of International Business and Cultural Studies, Maria L. Bullen and Kel-Ann Eyler (2010) explain that "[h] $\mathrm{h}$ uman resource accounting (HRA) involves accounting for the company's management and employees as human capital that provide future benefits. In the HRA approach, expenditures related to human resources are reported as assets on the balance sheet as opposed to the traditional accounting approach which treats costs related to a company's human resources as expenses on the income statement that reduce profit" (p. 1). Accurately accounting for employees as assets would properly categorize employees and related costs in the 
financial statements of a company. In theory, human asset accounting is an excellent idea with clear benefits. However, this is not to say that it can be done accurately in a non-complex or cost effective fashion.

\section{Why Accounting for Human Capital is So Difficult}

Human capital accounting is a highly complex process. In fact, it is so difficult that there has been no truly effective means ever developed. The complexity lies in the reality that there are hundreds of factors that comprise an employee's value. Additionally, employees are human beings with free will. Because they have free will, the employees can be influenced but never completely controlled like other assets can be. They cannot be owned like a building, patent, or security can be.

Although this suggests that free will makes accounting for human capital impossible, a method that could compute the value of an employee with reasonable accuracy can still be developed and have an immensely beneficial impact on the world of financial accounting. Figure 1 represents a 2005 Accenture poll of executives as to what extent they know about the return on their investment in human capital and it is indicative that there is a vast amount of room for improvement in the field of human asset accounting and the decision-making processes that rely on this information.

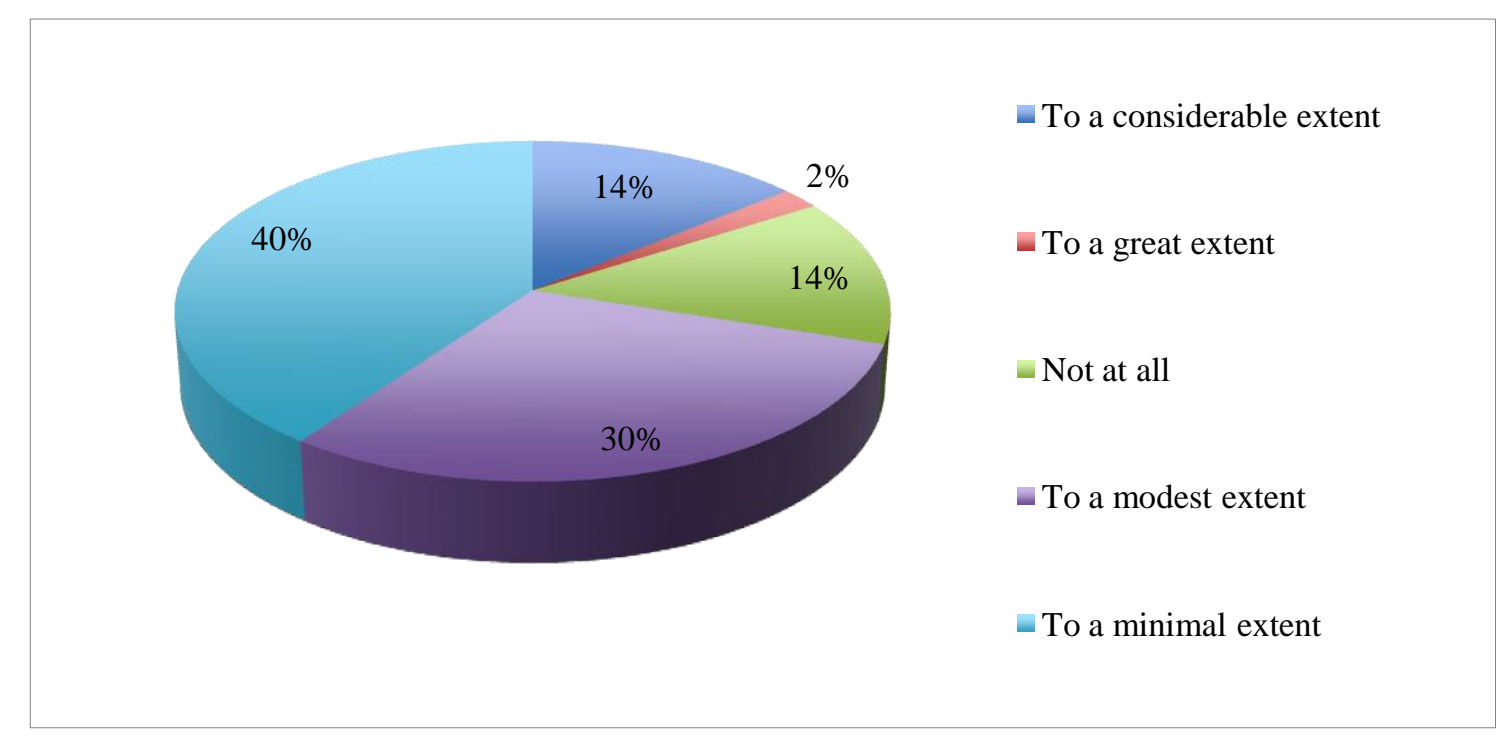

Figure 1: Understanding of Return on Investment in Human Capital

\section{HISTORY}

\section{Early Examples and Development}

Human resource accounting, in its most basic and fundamental form, can be identified as far back as the Medieval Age in Europe. When an enemy was captured, the capturers would have to decide if they should keep the prisoner alive or kill him. To do so, they calculated how much it would cost to keep the prisoner and how much they could potentially earn in the future from keeping the prisoner. If it was of benefit to keep the prisoner, they would; if not, the prisoner would be executed. Although very rudimentary, this marked a practical application of human asset accounting (Ahmed, 2010).

In 1691, Sir William Petty began to place values on laborers and estimated the value of human capital. He did so to estimate the cost of lives, mainly those that resulted from war. Additionally, he was able to show how powerful England was and support his claim with his calculations (Kiker, 1966). 
In 1776, Adam Smith popularized the idea that human beings were investments that generate returns. Smith claimed that human capital was:

the acquired and useful abilities of all the inhabitants or members of society. The acquisition of such talents, by the maintenance of the acquirer during his education, study, or apprenticeship, always costs a real expense, which is a capital fixed and realized, as it were, in his person. Those talents, as they make a part of his fortune, so do they likewise that of the society to which he belongs. The improved dexterity of a workman may be considered in the same light as a machine or instrument of trade which facilitates and abridges labor and which, though it costs a certain expense, repays that expense with a profit. (Smith, 1776)

Over the next century and a half, men like Jean Baptiste Say (1821), William Roscher (1878), Henry Sidgwick (1901), and John Stuart Mill (1909) began to expand upon Smith's theory and publish literature of their own that advanced the subject of human capital (Kiker, 1966).

William Farr expanded upon the idea of human capital in 1853. He theorized that the present value of a person's net future earnings represented wealth and that it should be taxed. He calculated it by taking the difference of a person's earnings and their living expenses, or what would today be called net income. Fourteen years later, Theodore Wittstein suggested that Farr's calculation could be beneficial when used in claims resulting from death (Kiker, 1966).

In the early twentieth century, Frenchman Alfred de Foville tried to estimate the value of capital stock. He did so by using Sir William Petty's method and subtracting consumption. Foville's countryman, actuary A. Barriol, attempted to place a "social value" on men. Foville used William Farr's method of taking the present value of a person's net future earnings; only he did not subtract consumption as Farr did. Barriol's calculations also differed based on the age group in which a person was categorized (Kiker, 1966).

In the early 1900's, human capital began to be realized as an item of importance in the insurance industry. Founder of the American College of Life Insurance at the University of Pennsylvania, Solomon Huebner expressed his belief that the value of human life should be treated scientifically the same way as other capital. Huebner understood the value that accurate estimates for underwriting could have in the insurance business. Prior to that, underwriting was not very accurate which had a negative impact on insurance companies (Kiker, 1966).

Wittstein's ideas enlightened Louis Dublin and Alfred Lotka in 1930. Dublin and Lotka were involved in the life insurance industry. They incorporated mortality statistics into Wittstein's theory to gain a better understanding of how much life insurance their clients needed. The new accuracy in estimations made their business more profitable and was a very significant finding in the insurance industry (Kiker, 1966).

\section{Modern Advancements in Human Asset Accounting}

Modern human asset accounting began to take form in the middle of the twentieth century in the United States of America. Rensis Likert, an organizational psychologist at the University of Michigan, was one of the forefathers of human resource accounting. He founded the University of Michigan Institute of Social Research in the 1960's and is renowned for his work regarding management styles and theory. Likert worked with R. Lee Brummet, William C. Pyle, and Eric Flamholtz on projects to cultivate ideas and methods of accounting for human capital (Bullen \& Eyler, 2010). The group is also responsible for the term "human resource accounting." They assessed the implications that human resource accounting could have on management decision-making; more specifically in "increasing managerial effectiveness in the acquisition, development, allocation, maintenance, and utilization of its human resources" (Bullen \& Eyler, 2010, p. 2). Their work inspired other research, theories, and methodologies and allowed human resource accounting to gain exposure.

\section{CURRENT FINANCIAL REPORTING ENVIRONMENT}

A scientist would be foolish to conduct a study in a lab without taking the environment of the study into account and assume that the study would produce the same results in any scenario. In the same way, it is essential that human asset accounting be viewed in the context of the current financial world. 
Shortly after the turn of the millennium, the financial reporting world was rocked with scandals such as Enron, WorldCom, Tyco International, and Waste Management, all of who were intentionally manipulating their financial records to paint a picture of a financially sound company. In reality, however, the companies were struggling financially and tampered with their accounting records in hopes of gaining investor confidence. The scandals led to new government mandates in financial reporting, most notably the Sarbanes-Oxley Act of 2002 (SOX), which is also known as the Public Company Accounting Reform and Investor Protection Act. The new mandates established the Public Company Accounting Oversight Board (PCAOB) to, as the name implies, oversee companies conducting audits of public companies. This was largely due to Arthur Andersen's failure to report Enron's fraud. In addition, it also placed more liability and responsibilities on auditors and company executives, extended the degree of financial disclosure required, and established tougher penalties for fraud.

The new regulations are essential to eliminating fraud and protecting investors, but they have also led to more involved calculations being used in the accounting profession. "GAAP has been moving toward adoption of more complex measurement methods in financial reporting compared with traditional historical cost approach to asset management" (Bullen \& Eyler, 2010, p. 3). This means that expected cash flows and fair market values are more appropriate to use than the traditional methods. Accounting for intangible assets has also gained momentum in accounting as regulators have begun to understand their importance to organizations. Intangible assets make up a larger part of companies' assets now than they ever have in the past. Flamholtz (1999) explains, "[e]fforts to determine the relationship between human resource investment information and the reflected value, as depicted in stock prices, have suggested that information regarding human resources is becoming more critical for accurate investment decisions, particularly in knowledge-based firms" (p. 14). The use of more complicated calculations and the growing importance of intangible assets demonstrate that financial accounting is heading in a direction where understanding and capturing the value of human capital is becoming increasingly important.

\section{IMPACT OF SOCIETAL SHIFT}

Over the past few centuries, the global economy has experienced a shift from an industrial to a knowledgebased society. The shift means that human capital and employees are more important than ever to companies and that companies' physical assets are less important than they have been historically. This is a result of the development of new technologies, most notably the Internet, and massive growth in the information sector. The Internet has provided a vast database of information that anyone can use, making it more important to know how to use it effectively in business than to simply have access to the information. This is one reason that employees are more important now than they had been previously. CEO of Allied Signal, Lawrence Bossidy states, "[a]t the end of the day, we bet on people, not strategies" (Accenture, 2005, p. 3).

Leading author of human resource accounting practices, Eric G. Flamholtz (1999), has recognized the importance of recognizing and understanding the societal change:

We have witnessed a significant transformation in the world economy and the organizations that comprise it. The economy of old was manufacturing-based and relied heavily on tangible assets as determinants of value. In contrast, the present day economy is based on knowledge and information, intangible assets that are embodied in people. This shift has triggered the development of tools with which to measure these intangible assets. One accounting tool that is directly relevant to the measurement and, in turn, the management of human capital is human resource accounting. (p. 11)

Industries that are heavily based on information and services rather than physical assets include, but are certainly not limited to, healthcare, information technology, education, and finance. Some of the world's most wellknown and profitable companies, including Google, Microsoft, Apple, IBM, Oracle, Facebook, Moody's Analytics, and Gartner, are heavily information-based. As of 1996, Microsoft's intangible to tangible ratio was 11 to 1 (Weatherly, 2003). It is no longer rare for a company's intangible assets to exceed tangible book assets by two to three times the value. This holds especially true with companies in the information sector.

Tangible assets accounted for almost all of a company's market capitalization in the 1980's. The shift began to occur and market and book values began to deviate from previous patterns (Weatherly, 2003). "This 
disassociation of market and book value meant that companies were now able to generate excess earnings" (Weatherly, 2003). Tangible assets generally do not exceed an entity's weighted average cost of capital and the book value of the assets. The excess earnings, therefore, were determined to be a result of a new type of asset intangible assets. In 1982, hard assets comprised $62 \%$ of a company's market value and by 1992, they had dropped to $38 \%$. Presently, hard assets only make up $20 \%$ to $30 \%$ of a company's market value (Weatherly, 2003).

Naturally, the growing importance of human capital and information has led to a greater emphasis on higher education. According to the National Center for Education Statistics (2011), enrollment in post-secondary institutions increased 9\% between 1989 and 1999. From 1999 to 2009, enrollment skyrocketed from 14.8 million to 20.4 million students, which represents an increase of 38\%. Over this time, full-time enrollment grew $45 \%$ as well, which also demonstrates the growing importance on higher education.

\section{INTANGIBLE ASSETS}

Intangible assets are non-monetary assets that do not have a physical form. They cannot be seen or touched and cannot be physically measured. Goodwill, intellectual capital, designs and processes, and human capital are all examples of intangible assets. Because they do not have physical substance, intangible assets are often difficult to measure and involve complex measurements and calculations. As shown in Figure 2, they differ from financial assets, such as securities and physical assets, such as property, plant and equipment and land. This does not mean, however, that intangible assets are any less important than financial or physical assets. In fact, intangible assets are often what set apart top companies from their competitors.

Intangible assets are held by a company to produce goods, to provide services, to rent or lease to other entities, and for administrative purposes (Weatherly, 2003). Because of their nature, intangible assets are often neglected or misrepresented in financial reporting. They are not acquired like other assets and, unfortunately for accountants, involve a deal of subjectivity and calculation. For example, if a brand is acquired, it can be recorded on the balance sheet at its historical cost. However, if the brand is built, it cannot be recorded on the balance sheet. Most intangibles do not depreciate over time like a machine or a plant does. In fact, many intangible assets appreciate over time (Roslender, 2009).

Within intangible assets, subsets have been identified - human capital and structural capital. Human capital pertains to employees and the attributes that they bring to an organization, such as education, training, experience, expertise, and flexibility, among many others. It is crucial to represent employees in human asset accounting as assets rather than how they have been accounted for as a cost (Roslender, 2009).

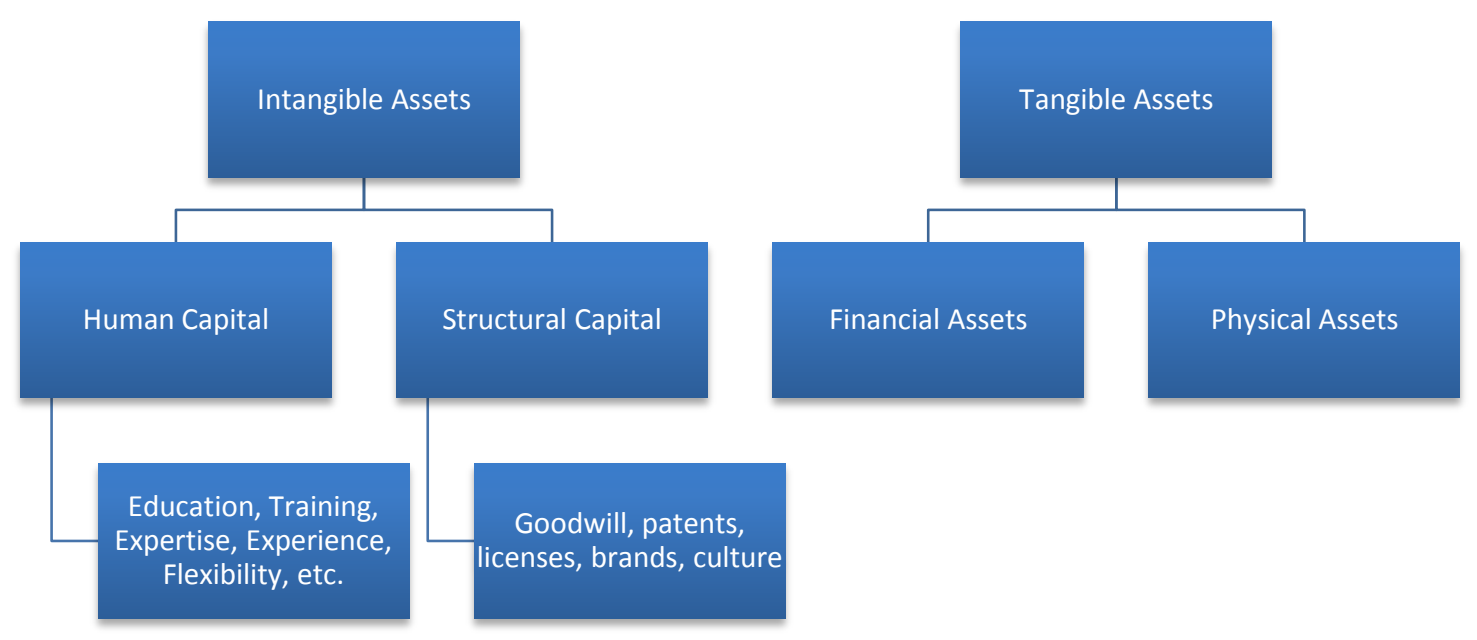

Figure 2: Intangible vs. Tangible Asset Breakdown 
In examining the nature and categorization of intangible assets, it is clear that they are difficult to account for. Within the intangible asset categorization, human capital is the most difficult subset to account for despite subjectivity involved in all of them. Human capital involves free will, which cannot be controlled, only influenced. Although it is a difficult task including complex measurements and calculations, it is essential to the accounting profession that advancements be made to improve human asset accounting to a point where it can be determined with reasonable accuracy and used in decision-making and reporting.

\section{METHODS OF HUMAN ASSET ACCOUNTING}

Many methods of accounting for human capital have been developed. None, however, have been sufficient enough to serve as an industry standard. Despite many methods showing promise, each falls short in certain ways. Methods of human asset accounting can be categorized into two main categories - cost approaches or value approaches.

Although these methods contain many concepts with great theoretical value, it is difficult to find them used in full in organizations today. One reason is that there is not currently one method that has been adopted as a standard. There is not a method that could be used across an industry. Each company and its employees are unique and organizations are becoming increasingly complex structures. Another reason is due to the difficulty in applying the approaches. The approaches are simply not inclusive enough to be applied to modern organizations. Additionally, much of the data is not readily available or available at all. The main reason that the current methods are not used more often, however, is that the methods have failed to produce results that companies have been able to gain great use from (Flamholtz, 1999).

\section{Cost Approaches}

\section{Historical Cost Method}

The historical cost method, which is one of the most well-known methods, calculates the value of human assets on the basis of their historical cost. These costs include recruiting, hiring, training, salaries and benefits, among others. The costs are capitalized and written off over the course of the expected life of the asset, which, in this method, is the employee. The unamortized part of the cost remains on the entity's books and is written off against the profit and loss account at year-end. If the asset's life exceeds expectations, then a recalculation and rescheduling occurs. The historical cost method was developed by Brummet, Flamholtz, and Pyle and first applied at R.G. Berry Corporation in 1967 (Fitz-enz, 2000). As with other human asset accounting methods, there is a great deal of estimation involved, especially in determining the service time aspect. Additionally, there is an underlying assumption that the dollar is stable, which it is not. It measures the cost to an organization, but not the value of the employee to the organization (Bullen \& Eyler, 2010).

\section{Replacement Cost Method}

The replacement cost method is relatively straightforward. It determines the financial implications of replacing the person currently holding the position that would be replaced. This includes recruiting, selecting, compensating, and training, as well as income foregone during the period. It can also involve replacing a specific aspect of that employee's position. Although easy to calculate, the replacement cost method lacks depth in analysis, which is why it proves insufficient in accurately determining an employee's worth. Additionally, a company who is inefficient in replacing employees would incur a greater cost than one who does it more efficiently.

\section{Competitive Bidding Method}

The competitive bidding method, also known as the opportunity cost method, involves opportunity cost and how it relates to scarcity of resources in a company. Bidding is done between departments and the determined earning potential of each employee is then capitalized by the company and treated as a capital asset. The main problem with this method is that it assumes that the people doing the bidding are competent in their bidding and are offering salaries to the employee that do not grossly overestimate or underestimate the actual value of the employee to the employee. The competitive aspect also can lead to overvaluation by driving up the value of an employee. 


\section{Standard Cost Method}

In the standard cost method, the costs of recruiting, hiring, training, and developing employees are calculated annually. The total standard cost is calculated to value all of a company's human resources. This approach only produces a total and fails to assign value to individual employees. Because it only produces a total, the data is not very helpful when making decisions that do not include the entire organization. It also fails to realize that the employees will bring future value to the organization (Monti-Belkaoui \& Riahi-Belkaoui, 1995).

\section{Cost Benefit Method}

The cost benefit method involves two calculations. First, the total benefit the employee provides the company with is determined. Then the benefit that the company provides to the employee, such as salary and benefits, is calculated. The difference between the benefits the employee provides the company with and the benefits the company provides the employee with is the real value of the employee. The cost benefit method involves too much subjectivity and fails to recognize future implications, and it is therefore limited in its application (Fitz-enz, 2000).

\section{Value Approaches}

\section{Jaggi and Lau Method}

The Jaggi and Lau method organizes employees into groups. By doing so, Jaggi and Lau sought to eliminate the difficult task of predicting promotions and employees leaving the company since it is easier to predict patterns of groups than it is to predict patterns of individual employees. From there, the value of each human resource group is evaluated. The thought is that the human resource groups account for productivity and performance in companies. One issue with this method is that it uses estimates which are largely subjective. It also fails to assign value to individual employees by using groups.

\section{Economic Value Method}

The net present value of incremental cash flows credited to human resources is determined to be the value of the asset in the economic value method. The organization must decide which cash flows to attribute to human resources, which requires subjectivity. Due to its incremental nature, it is updated frequently, which also means it is labor intensive. Like many other methods, the economic value method fails to assign individuals with value within the organization, which does not help managers determine how to handle any situations regarding individual employees.

\section{Lev and Schwartz Method}

The present value of future earnings method - more commonly known as the Lev and Schwartz method - is arguable the most scientific method as it provides a formula. It takes into account the present value of future employee earnings, as the name suggests. Lev and Schwartz developed this model in 1971. Shortly thereafter, Flamholtz adjusted the formula to take into account the possibility of employees leaving the organization. The formula is as follows:

$$
\begin{array}{ll}
\mathrm{E}(\mathrm{Vy})= & \varepsilon \mathrm{Py}(\mathrm{t}+1) \varepsilon \mathrm{I}(\mathrm{T}) /(\mathrm{I}+\mathrm{R}) \mathrm{t}-\mathrm{y} \\
\mathrm{E}(\mathrm{Vy}) & =\text { expected value of a person who is y years old human capital } \\
\mathrm{T} & =\text { projected retirement age } \\
\mathrm{Py}(\mathrm{t}) & =\text { probability of the person leaving the company } \\
\mathrm{I}(\mathrm{t}) & =\text { expected earnings of the employee over a given time period } \\
\mathrm{R} & =\text { discount rate }
\end{array}
$$


The measure is relatively objective and uses information from censuses and mortality tables. The approach is limited because it uses averages as opposed to evaluating individual situations (Monti-Belkaoui \& Riahi-Belkaoui, 1995).

The Lev and Schwartz model is the most common in application and is used commonly in India. It is used by companies such as Infosys, Saytam Computers, and BHEL.

\section{Expense Model}

Mirvis and Macy developed the expense model in 1976. It attaches dollar value estimates to behavioral outcomes that are brought about by working in an organization. The values associated with the behavioral outcomes do not possess objectivity as they are being assigned to outcomes that are based on human free will. Items such as absenteeism, turnover, and performance are measured and then the costs are estimated for each. This method fails to recognize many of the factors involved in an employee's value (Mirvis \& Macy, 1976).

Table 1 summarizes the above cost vs. value methods.

Table 1: Cost vs. Value Methods of Human Asset Accounting

\begin{tabular}{lc}
\hline \multicolumn{1}{c}{ Cost Methods } & Value Methods \\
\hline Historical Cost & Jaggi and Lau \\
Replacement Cost & Economic Value \\
Competitive Bidding & Lev and Schwartz \\
Standard Cost & Expense \\
Cost Benefit & \\
\hline
\end{tabular}

\section{Determinants of Employee Value}

Many of the models discussed above use different inputs to value an employee. None of them are by any means all-inclusive. It is important to examine factors that contribute to an employee's productivity. These factors fall into several different categories, each important in their own way (see Figure 3).

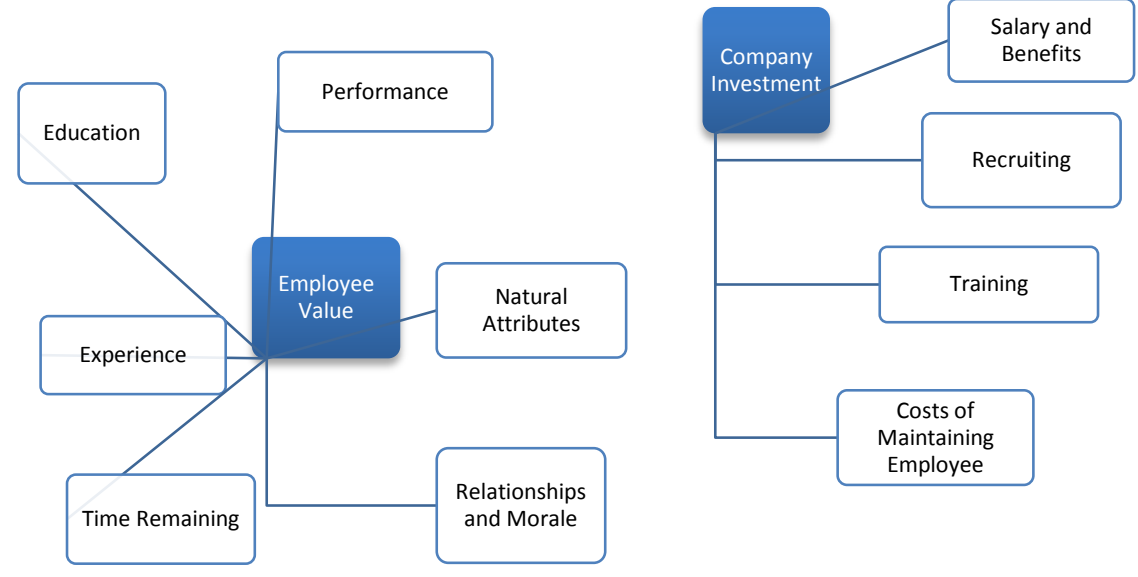

Figure 3: Inputs Used to Determine Employee Value

Education is one important way to capture an employee's value. Education includes elements such as schooling, work training, external training, and certifications and degrees. The more schooling and training an employee has, the more likely they are to bring greater value to an organization. This is not always true as natural 
intelligence and other factors are also vital, but it is generally a good indication. Education is often represented in employee salaries, but should not always be.

For example, consider two accountants hired to the same position in the same company at the same time. One is from an Ivy League school and will be paid \$5,000 more annually than the other new hire who attended a public university. By paying the Ivy League accountant more, the company's human resource department is essentially stating that he is of more value to the company than the public school accountant, which is not necessarily true. The public university accountant could be more motivated, better at communicating and building relationships, and simply more productive than his Ivy League counterpart. For this reason, it is critical that many factors be taken into consideration when determining the value that an employee brings to an organization and not just obvious factors such as salary or education.

Salary and other benefits also play an important role in determining employee value, especially in an approach that nets the employees value and costs associated. Salary and benefits are investments that are associated with the expected return of the employee. The greater the difference between the value and the cost is, the better the investment by the company. The same is true for recruiting and training costs associated with obtaining the employee in the first place.

Employee value must be captured mainly through performance in their role. Although difficult, employee reviews by managers and other data; for example, sales numbers for a salesman or deliverables met for an IT professional, must be quantified and taken into account.

The natural attributes an employee has are also important. A good, charismatic speaker is likely to better sell ideas or products. A naturally intelligent person, whether they attended college or a training class or not, can obviously still be of great value to a company if they are good at what they do. Certain attributes that are crucial to success in one industry can be of little help in another.

Job experience is also crucial to the value that an employee can provide the company. If an issue arises that an employee has previously experienced, they will be much more likely to resolve it in a timely, effective manner. Generally, the more time spent in a job or industry, the more knowledge and people that employee will gain and know. They are also able to impart their experience to other employees.

Relationships are crucial in any organization. For example, if an employee has a good relationship with an outside vendor, they will likely be able to get extra benefits from the vendor than a person with whom the vendor has no rapport. Relationships within the organization are also vital. If employees know each other and get along, they will be much more likely to work through a project efficiently and without issue. Employees that get along can keep morale high, which leads to a better work environment and greater productivity.

Time left with a company is also important, as seen by its inclusion in many models. If an employee is going to be capitalized as an asset, there must be a good idea of the "useful life" of the employee or for how much time they will remain with the company. Retirement, leave, and death are all reasons that must be taken into account. A similar application is how companies account for pension plans. All of these factors play a role in determining the actual value of an employee.

It is not sufficient to examine the ability of individuals to an organization without determining how well a company utilizes their value. There are other factors that must be considered in attempting to place a value on individuals. As discussed previously, service companies generally hold more of their value in employees than other assets. For this reason, it is crucial to consider the industry that the company is in and the product or service that they provide in deciding how important an individual is. Additionally, the degree to which the company integrates employees and intelligence into their operations and culture have an effect on how much value an employee can add to an organization (Flamholtz, 1999). It is not only the ability that an employee possesses, but also how they use that ability to make the product or service they provide more valuable. 


\section{CONCLUSION}

There is no question that employees bring tremendous value to their respective organizations and make up the workforce that keeps the world and its economy running, as seen in examining the history and importance of human asset accounting. This value, however, is not easily measured or accounted for which poses the problem of 'how can we account for our most important asset?' No current method is accurate enough to be used as a standard for financial reporting. A more inclusive method, with more of the elements previously discussed, must be developed. Further complicating the issue is that human asset accounting attempts to assign a value to a being with free will, which is the main reason that human capital is different than other intangible assets.

The past century has produced new developments and laid the groundwork of human asset accounting that must be built upon. The direction that financial reporting is heading in, growing importance of intangible assets to organizations, and desire to capture the value of human capital worldwide are all highly encouraging to the future of human asset accounting. Improvements must continually be made, however, as an accurate method of accounting for humans as assets would forever change the landscape of managerial decision-making and the accounting profession. In the meantime, the authors recommend that as a precursor to measurement, the development of general quantitative and qualitative human capital disclosures, with real company examples, be included in a company's sustainability reporting.

\section{AUTHOR INFORMATION}

Brian Stanko, Ph.D., CPA received a Ph.D. in Accounting from the University of Kentucky. He is currently Department Chair and MSA Program Director at Loyola University Chicago. Professor Stanko's primary research and writing interests concern financial reporting standards and the understanding of corporate annual reports. He is the coauthor of three books and has published articles in The Journal of Accounting and Public Policy, Issues in Accounting Education, Journal of Business and Economic Research, Corporate Controller, The Government Accountants Journal, Strategic Finance, Journal of Business Ethics, The CPA Journal, and International Advances in Economic Research. Professor Stanko's teaching responsibilities have included principles, intermediate, and graduate level accounting courses. E-mail: bstanko@luc.edu (Corresponding author)

Thomas L. Zeller, CPA, PhD is a Professor of Accounting in the Department of Accounting and Business Law at Loyola University Chicago, Quinlan School of Business. He has published numerous articles and books. His research appears in a wide variety of academic and practitioner journals, including Strategic Finance, Journal of Accounting and Public Policy, Journal of Business and Economic Research, Business Horizons, Healthcare Financial Management, and Issues in Accounting Education. He routinely presents to professional groups and businesses on topics addressing financial analysis, activity-based costing, and business measurement. He teaches graduate and undergraduate level courses in accounting at Loyola. He is actively involved as a Center for Corporate Financial Leadership (CCFL), a division of the Illinois CPA Society teaching seminars in financial measurement and capital budgeting. He is a member of the American Accounting Association, Illinois CPA Society and American Institute of Certified Public Accountants. E-mail: tzeller@luc.edu

Matthew Melena is presently a candidate for the Master of Science in Accounting degree at Cleveland State University. A graduate of Loyola University Chicago, he is now employed as a business analyst for a Cleveland, Ohio health insurance company. E-mail: mattmelena@gmail.com

\section{REFERENCES}

1. Accenture. (2005). The Accenture human capital development framework: Assessing, measuring, and guiding investments in human capital to achieve high performance ( $1^{\text {st }} \mathrm{ed}$.).

2. Ahmed, A. (2010). Human resource accounting (HRA): Techniques and accounting treatment. Institute of Chartered Accountants of Bangledash Working Paper Series, June 2010.

3. Brocaglia, J. (2006, August). The importance of human capital. ISSA Journal. 
4. Bullen, M. L., \& Eyler, K.-A. (2010). Human resource accounting and international accounting developments: Implications for measurement of human capital. Journal of International Business and Cultural Studies, 3.

5. Fitz-enz, J. (2000). The ROI of human capital, measuring the economic value of employee performance. Amacom Books.

6. Flamholtz, E. G. (1999). Current issues, recent advancements, and future directions in human resource accounting. Journal of Human Resource Costing and Accounting, 4(1), 11-20.

7. Kiker, B. F. (1966). The historical roots of human capital. Journal of Political Economy, 74(5), Retrieved from http://www.jstor.org/pss/1829595

8. Mirvis, P. H., \& Macy, B. A. (1976). Accounting for the costs and benefits of human resource development programs: An interdisciplinary approach. Accounting, Organizations and Society, 1(2), 179-193.

9. Monti-Belkaoui, J., \& Riahi-Belkaoui, A. (1995). Human resource valuation: A guide to strategy and techniques. London: Quorum Books.

10. Parameswaran, R. (2005). Human resource accounting. The Chartered Accountant, 1, 867-874.

11. Roslender, R. (2009). The prospects for satisfactorily measuring and reporting intangibles: Time to embrace a new model of (ac)counting? Journal of Human Resource Costing and Accounting, 13(4), 338359.

12. Smith, A. (1776). An inquiry into the nature and causes of wealth of nations book 2 - of the nature, accumulation, and employment of stock.

13. U.S. Department of Education, National Center for Education Statistics. (2011). Education statistics. Retrieved from http://nces.gov/fastfacts/display.asp?id=98

14. Weatherly, L. A. (2003). Human capital-the elusive asset: Measuring and managing human capital. Research Quarterly, 15. 